\title{
Constitutional developments since the Lisbon Treaty in the area of freedom, security and justice at supranational and national level
}

\author{
by Alfred Kellermann
}

In order to evaluate the constitutional developments in the area of freedom, security and justice (AFSJ) of the Lisbon Treaty, this article begins with a tour d'horizon of the new provisions in the field of AFSJ. Their impact on the supranational and national constitutional legal orders is discussed, and the differences with the Treaty of Nice. There is also a review of some European Court of Justice cases interpreting the old Third Pillar instruments and comparing them with the new Lisbon challenges.

\section{INTRODUCTION TO THE NEW AFSJ PROVISIONS OF THE LISBON TREATY}

The Lisbon Treaty has brought all provisions concerning freedom, security and justice within the normal treaty structure. As a consequence, the jurisdiction of the European Court of Justice (ECJ) extends to all EU law including AFSJ. The preliminary rulings procedure has been adapted to the needs of AFSJ (Arts 267 and 276 TFEU) with exceptions for reviewing police and other lawenforcement services and safeguarding internal security. For criminal cases an urgent preliminary procedure was introduced.

The new version of the infringement procedure (Arts 259 and 260 TFEU) according to which the Commission - in a case where a Member State has failed to notify measures transposing a Directive under a legislative procedure - can already in a first instance propose the EU Court to impose a lump sum or a penalty payment on the Member State concerned. This new version can contribute to a better and timely implementation of EU law obligations.

The Lisbon Treaty made significant changes to the EU's architecture by removing the Third Pillar and replacing it by AFSJ, which means that the European Community rules apply to the AFSJ as well. We consider this as the "communitarisation" of the AFSJ. The consequence from this will be more transparency, more efficiency and more similarity with the legal effect (primacy, direct effect) of the rule of law in the internal market.

The provisions of the AFSJ are included in Articles 6789 TFEU (Treaty on the Functioning of the EU) in the following five chapters:

Chapter 1 General provisions;

Chapter 2 Policies on border checks, asylum and immigration;

Chapter 3 Judicial cooperation in civil matters;

Chapter 4 Judicial cooperation in criminal matters; and

Chapter 5 Police cooperation areas.

The EU's objectives as contained in Article 3 TEU (Treaty on European Union) of the Lisbon Treaty are renewed and hold the following provisions:

"2. The Union shall offer its citizens an area of freedom, security and justice without internal frontiers, in which the free movement of persons is ensured in conjunction with appropriate measures with respect to external border controls, asylum, immigration and the prevention and combating of crime. 


\section{The Union shall establish an internal market. [...]".}

In Article 3 TEU the AFSJ has "moved up" the list, and is now placed before the internal market. This shows the interest and importance this area has attracted.

The AFSJ is further deemed to be an area, like the internal market, that falls within shared competence. However in Article 2(2) TFEU: "Shared competence between the Union and the Member States" the internal market (a) is higher on the list than the area of freedom, security and justice (j).

Why in areas of power sharing is the AFSJ placed behind the internal market? Is power sharing for the AFSJ less important? The answer might be that the Union powers are limited and not always clear as regards the many opt outs and opt ins. The exact powers are not always easy to find as there are many treaties on judicial cooperation which are also outdated. The nature of power sharing in the internal market as well as in AFSJ between the EU and the Member States can only be determined by looking to the detailed provisions, and the judicial interpretation thereof.

Member States will only lose their competence within the regime of shared power to the extent that the Union has exercised "its" competence. Competences which are not transferred to the EU still remain with the Member States. Perhaps in AFSJ the Member States fear to loose their competences, more than in the internal market.

The magnitude of AFSJ powers at supranational level will therefore be dependant on the way the Member States have exercised their national competences in the area of freedom, security and justice.

\section{THE LEGAL ACTS OF THE AFSJ}

The general regime of legal acts specified in the Articles 288-294 TFEU of the Lisbon Treaty applies to measures adopted in the AFSJ. The institutions can now adopt as legal acts: regulations, directives and decisions. These acts are replacing the acts under Article 34 EU of the Treaty of Nice (common positions, framework decisions, decisions, conventions). The framework decision is the equivalent of the Lisbon Directive, however in Article $34 \mathrm{EU}$ is stated that they will not have direct effect (see J W de Zwaan/A J Bultena, Ruimte van Vrijheid, Veiligheid en Rechtvaardigheid, published by SDU 2002, p 78; Jaap W de Zwaan, Flora Goudappel, Freedom, Security and Justice in the European Union: Implementation of the Hague Programme 2004, Cambridge University Press; Paul Craig, The Lisbon Treaty, Law, Politics and Treaty Reform, ch 9 - Freedom, Security and Justice, Oxford University Press, 2010 p 340).

On the contrary in the Lisbon Treaty a legislative, delegated or implementing Directive dealing with AFSJ can have direct effect, provided that it satisfies the criteria for this doctrine.

In this area clashes between the Union acts and national constitutional provisions may be expected. The question may rise if there is a difference of the constitutional effect of legal acts dealing with the AFSJ or with matters of the internal market. Do they have similarly priority or primacy on the national legal order (constitution and laws)?

\section{THE PRINCIPAL OBJECTIVES OF THE AFSJ}

Article 67 TFEU is the main provision for the AFSJ in the Lisbon Treaty:

(1) The Union shall constitute an area of freedom, security and justice with respect for fundamental rights and the different legal systems and traditions.

(2) It shall ensure the absence of border internal controls and a common policy on asylum, immigration and external border control.

(3) Combat crime, racism and xenophobia through police and judicial cooperation and through mutual recognition of judgments in criminal matters and through approximation of criminal laws.

(4) The Union shall facilitate access to justice, in particular through the principle of mutual recognition of judicial and extrajudicial decisions in civil matters.

These provisions are replacing Article 61 EC and ex Article 29 TEU from the Third Pillar which initiated many Framework Decisions and other measures that are interpreted in several judgments of the European Court of Justice, before the entry into force of the Treaty of Lisbon. In the following we selected some of the judgments, in which the implementation of these objectives has been discussed and comment on the differences with the Lisbon Treaty.

\section{PROTECTION OF FUNDAMENTAL RIGHTS LIMITING THE EFFECT OF UN, EU AND NATIONAL DECISIONS ON PREVENTING AND COMBATING TERRORISM}

In its judgment of September 3, 2008 on economic sanctions on individuals pursuant to a UN Resolution, the European Court of Justice has made it clear in joined Cases C-402/05 P \& C-415/05 P Kadi \& Al Barakaat $v$ Council of the European Union [2008] ECR I-635 that in all circumstances the fundamental rights of EU citizens must be respected when adopting measures in the EU, including the rights of fair trial and regardless of international obligations. The judgment:

(1) Sets aside the judgments of the Court of First Instance of the European Communities of September 21, 2005 in Case T-315/01 Kadi v Council and Commission and Case T-306/01 Yusuf and Al Barakaat International Foundation v Council and Commission.

(2) Annuls Council Regulation (EC) No 881/2002 of May 27, 2002 imposing certain specific restrictive measures directed against certain persons and entities associated with Usama bin Laden, the Al-Qaeda network and the 
Taliban, and repealing Council Regulation (EC) No $467 / 2001$ prohibiting the export of certain goods and services to Afghanistan, strengthening the flight ban and extending the freeze of funds and other financial resources in respect of the Taliban of Afghanistan, in so far as it concerns Mr Kadi and the Al Barakaat International Foundation.

(3) Orders the effects of Regulation No 881/2002 to be maintained, so far as concerns Mr Kadi and the $\mathrm{Al}$ Barakaat International Foundation, for a period that may not exceed three months running from the date of delivery of this judgment.

The ECJ overruled the judgments of the Court of First Instance (CFI) because it found a breach of fundamental rights of the European Union. The Council Regulation freezing Mr Kadi and Al Barakaat's funds was annulled because the ECJ found that the rights of the defence, in particular the right to be heard, and the right to effective judicial review of those rights, were not respected. The court further concluded that the freezing of funds constituted an unjustified restriction of Mr Kadi's right to property.

This judgment opens a wide range of interpretations regarding the interplay between international law implementing EU law and conflicting national legislation in the AFSJ.

In this case the acts of the European Union were to be seen as a direct implementation of Security Council Resolution 1267 (1999). Yusuf and Kadi had argued that the contested regulation infringed their fundamental rights, in particular their right to the use of their property and the right to a fair hearing, as guaranteed by Article 6 of the European Convention for the Protection of Human Rights and Fundamental Freedoms (ECHR), inasmuch as that regulation imposed on them heavy sanctions, both civil and criminal, although they had not first been heard or given the opportunity to defend themselves, nor had that act been subjected to any judicial review whatsoever. With more particular regard to the alleged breach of the right to a fair hearing, the applicants stressed that they were not told why the sanctions were imposed on them.

Article 75 TFEU of the Lisbon Treaty has been designed in order to address the legal problems that arose in the Kadi litigation with the annulment of Council Regulation No $881 / 2002$ over freezing of assets of natural or legal persons in case of Counter-Terrorist Policies and Fundamental rights and priority of Security Council Decisions. That article grants the EU the power to adopt restrictive measures against individuals such as freezing of funds, financial assets or economic gains belonging to, or owned or held by natural or legal persons, groups or non-state entities.

By including Article 75 TFEU in the Lisbon Treaty, the Kadi case has a constitutional impact on the supranational legal order. Kadi shows further the impact of the development of the legal effect of decisions and resolutions of international organisations on the EU legal order and as a consequence also on the national legal order.

The developments in the international legal order have also an effect on the interpretation of international treaties in the Netherlands constitution and its priority on Dutch laws. According to the theory of "neo-monism", the priority of international decisions in the Netherlands will from now on be limited by the fundamental principles in the Dutch constitutional and legal order, which are identical with the principles of the infringed fundamental rights in the Kadi case (see R A Wessel, "The Kadi Case: Towards a More Substantive Hierarchy in International Law?", International Organizations Law Review 5 (2008) 323 27. Bogdandy is referred to as follows:

"There should always be the possibility, at least in liberal democracies, to limit, legally, the effect of a norm or an act under international law within the domestic legal order if it severely conflicts with constitutional principles. This corresponds to the state of development of international law and the sometimes debatable legitimacy of international legal acts [...]" (emphasis added) (see A von Bogdandy, "Pluralism, Direct Effect, and the Ultimate say: On the Relationship between International and Domestic Constitutional Law," International Journal of Constitutional Law, 2008, Nos 3-4, 397-413, p 400).

Our final comment and conclusion are that for acts (regulations, directives) adopted under Articles 288-294 TFEU in the field of combating terrorism, the direct effect will similarly as in the Kadi case be limited by fundamental rights in the Netherlands legal order, also after the entry into force of the Lisbon Treaty. The court's fundamental rights role will also be enhanced as a result of the binding legal status of the Charter of Fundamental rights of the European Union, now that it has been adopted with the Lisbon Treaty. Articles 47-49 of the Charter are relevant when considering fundamental rights safeguards in criminal proceedings. An exception is made for Poland and the UK, against whom the Charter cannot be invoked.

\section{CONSTITUTIONAL DEVELOPMENTS IN DECISION-MAKING}

\subsection{The role of national Parliaments}

The role of national Parliaments has been enhanced. For example the provisions of Article 69 TFEU (subsidiarity principle) and Article 70 TFEU (evaluation of Union policies as for example monitoring Europol and Eurojust), and the setting up within the Council of a standing committee in Article 71, about whose activities the national Parliaments will be informed, are a remarkable constitutional development. In the field of judicial cooperation in civil matters according Article 81(3) TFEU a national Parliament can veto the adoption of a decision of the Council on issues of family law having cross-border implications. 


\subsection{Cross-border dimension of the crime}

The EU's competence to enact measures concerning criminal law is now specified in Article 83 TFEU: terrorism, trafficking in human beings and sexual exploitation of women and children, illicit drug trafficking, illicit arms trafficking, money laundering, corruption, counterfeiting of means of payment, computer crime and organised crime. Cross border dimension of the crime is a requirement. Prior to the Lisbon Treaty doubts as to the EU competence over criminal procedure existed.

\subsection{Protection of fundamental aspects of the national criminal justice system}

In paragraphs 3 of Articles 82 TFEU and 83 TFEU there are identical "emergency brakes":

"Where a member of the Council considers that a draft directive as referred to in paragraph 2 would affect fundamental aspects of its criminal justice system, it may request that the draft directive be referred to the European Council. In that case the ordinary legislative procedure shall be suspended. The sensitivity of the area led to the invention of the "emergency brake" (emphasis added).

\subsection{Recognition of judgments and approximation of laws in criminal matters}

In the field of judicial cooperation in criminal matters (Arts 82(3) TFEU and 83(3) TFEU) it is regulated that judicial cooperation shall be based on the principle of mutual recognition of judgments and judicial decisions and shall include the approximation of laws and regulations of the Member States in the referred areas.

The European Parliament and the Council acting in accordance with the ordinary legislative procedure shall adopt the necessary measures.

Since the Tampere Conclusions (1999), the principle of mutual recognition has been seen as the cornerstone of European criminal law. The application of this principle can only be successful if there is mutual trust among Member States in each other's legal systems, which will be more easily achieved if some form of harmonisation (of both substantive and procedural criminal law) has taken place. The centrality of mutual recognition is now laid down in the Lisbon Treaty. The application of mutual recognition to the criminal sphere has however not been unproblematic, as mutual recognition in the criminal sphere cannot be compared with the concept of free movement of goods in the internal market.

In relation to police cooperation, and especially with regard to information exchange, the fundamental rights of individuals are threatened in two areas: data protection and legal protection. Fundamental rights concerns in the area of judicial cooperation relate to adopted acts on mutual legal assistance, extradition, execution of sentences etc.
According to the principle of mutual recognition, decisions taken in one Member State are recognised and executed throughout the EU, based on the presumption that all EU Member States have a sufficient system of criminal procedure, including a sufficient level of fundamental rights protection. It is clear that this system presupposes mutual trust. The lack of trust among Member States in each other's legal systems is a bottle neck and impediment to the further application of mutual recognition in the field of judicial cooperation.

\section{EUROPEAN ARREST WARRANT IN THE AREA OF JUDICIAL COOPERATION}

The Council Framework Decision 2002/584/JHA of June 13, 2002 on the European arrest warrant and the surrender procedure between Member States, OJ L 19/1, ("EAW") is probably the most debated and at the same time most used instrument in the European criminal law, providing for a simplified and fast procedure for the surrender of suspects and convicted persons between Member States. The number of EAWs issued has increased from approximately 3000 in 2004 to 13500 in 2008. The EAW is the first legal act to apply mutual recognition in criminal matters.

In the preamble to the Framework Decision on the EAW, reference to respect for human rights has been included in Recital 12. However a (possible) violation of human rights has not been adopted as a ground to refuse the surrender. Another ground for refusal in pre-EAW extradition law is the non-extradition of own nationals. There are many interesting court cases on the interpretation of the terms in the EAW, for example on the grounds to refuse cooperation, double criminality requirements, on previous crimes as in C-66/08 Kozlowski [2008] ECR I-6041; C-123/08 Wolzenburg [2009] ECR I9621; C-388/08 Leymann [2008] ECR I-8993; C-303/05 Advocaten voor de Wereld VZW, [2007] ECR I-3633.

In this overview we will only focus on the questions put forward in Case C-303/05 Advocaten voor de Wereld. In 2005 three Member States' constitutional courts (Polish, German and Cypriot) reviewed and declared as unconstitutional their national acts implementing the EAW Decision. It became clear that, if national courts want, they can block the practical operation of a third pillar measure. The association "Advocaten voor de Wereld" brought an action before the Belgian Arbitragehof/Cour d'Arbitrage (Court of Arbitration), currently the Constitutional Court, seeking the annulment of the Belgian Law transposing the provisions of the Framework Decision of the EAW and the surrender procedures between Member States. The Belgian court referred to the Court of Justice for a preliminary ruling several questions concerning the validity of the Framework Decision.

With respect to the first claim, that the subject matter of the EAW ought to have been regulated by means of a 
convention and not a framework decision, the court in its judgment of May 3, 2007 found that (ex) Article 34 EU does not establish any order of priority between the different instruments listed in that provision (common positions, framework decisions, decisions, conventions), with the result that it cannot be ruled out that the Council may have a choice between several instruments in order to regulate the same subject-matter, subject to the limits imposed by the nature of the instrument selected.

The second question concerned the infringement of the principle of legality of criminal offences and penalties (nullum crimen, nulla poena sine lege) and non-discrimination. Article 2(2) of the EAW Framework Decision contains a list of 32 offences in respect of which the usual condition of double criminality is dispensed with, if those offences were punishable in the issuing state by a custodial sentence or a detention order for a maximum period of at least three years.

The court recalled the principle of the legality of criminal offences and penalties which principle implies that legislation must define clearly offences and the penalties which they attract. That condition is met in the case where the charged individual is in a position on the basis of the wording of the relevant provision and with the help of the interpretative assistance given by the courts, to know which acts or omission will make him criminally liable.

Finally the court in its judgment of May 3, 2007 found no factor capable of affecting the validity of the Framework Decision on the EAW. The observations of the Advocate General Colomer in this case are of interest:

"79. Accordingly, the Court must break its silence and recognise the authority of the Charter of Fundamental Rights as an interpretative tool at the forefront of the protection of the fundamental rights which are part of the heritage of the Member States. That undertaking must be approached with caution and vigour alike, in the full belief that, while the protection of fundamental rights is an essential part of the Community pillar, it is equally indispensable in the context of the third pillar, which, owing to the nature of its subjectmatter, is capable of affecting the very heart of individual freedom, the foundation of the other freedoms.

80. In that way it might be possible to avoid repeating past misunderstandings with national courts which have been reticent about the capacity of the Community Institutions to protect fundamental rights. [...]"

These observations are more or less implemented since the entry into force of Article 6(1) of the TEU of Lisbon Treaty: the Charter of Fundamental Rights shall have the same value as the Treaties. National standards of review can now safely be replaced by European standards, and this protection is not less than the one offered by national constitutions.

\section{PUPINO AND THE OBLIGATION OF CONSISTENT INTEPRETATION}

In 2001 the EU has introduced the Council Framework Decision 2001/220/JHA of March 15, 2001 on the standing of victims in criminal proceedings, OJ 2001 L 82/1. Under Article 8 of the Framework Decision Member States were required to ensure that where there was a need to protect victims - particularly those most vulnerable from the effects of giving evidence in open court, victims may, by decision taken by the court, be entitled to testify in a manner which will, enable this objective to be achieved, by any appropriate means compatible with its basic legal principles.

The question arose before a Italian court whether the special inquiry procedure reserved for sexual offences should also be extended to cases of children victims as a result of the principle of indirect effect of Third Pillar measures. Such interpretation could be required by the obligation to interpret national law consistently with the framework decision.

In the Pupino case (C-105/03, Criminal Proceedings against Maria Pupino [2005] ECR I-5285) the ECJ held that the obligation of "consistent interpretation" existed in the context of the Third Pillar. The ECJ stated that this Decision could not have direct effect. However it did not preclude indirect effect.

Maria Pupino was a nursery school teacher. She was accused of inflicting injuries on pupils less than five years old. The prosecutor in the case asked the Italian court to make use of a special inquiry procedure, by which the children witnesses could be examined in more childrenfriendly conditions. According to Italian law this was not possible. However it became possible, thanks to the interpretation of the Framework Decision, as the ECJ did in Pupino.

This constitutional phenomenon of "conforming interpretation" is the result of the Pupino decision and it opened up EU law for further questions like the question if EU law can be supreme (see K Lenaerts and T Cofthaut, "Of Birds and Hedges: the Role of Primacy in invoking Norms of EU Law" (2006) 31 EL Rev 287; J H. Reestman and F A N J Goudappel, in De Europese Unie na het Verdrag van Lissabon, Editors R $\mathrm{H}$ van Ooik and R A Wessel, Hoofdstuk 14 Het Verdrag van Lissabon en de ruimte van vrijheid, veiligheid en recht, p 175).

Some commentators contended that the Third Pillar was less intergovernmental than was commonly thought.

The ECJ considered further that the principle of "conforming interpretation" was more or less based on the principle of loyal cooperation and therefore also applicable to the area of police and judicial cooperation in criminal matters.

The application in the Third Pillar of loyal cooperation (based on Art 10 EC) was disputed by some intervening parties. Since (ex) Article 10 EC was more or less replaced 
by Article 4(3) EU of the Lisbon Treaty this will after Lisbon not be anymore a dispute. Further would after Lisbon an identical court judgment be expected as stating that the "Directive" replacing the Framework Decision could have direct effect, without the need to refer to "consistent interpretation" or "indirect effect".

\section{CONCLUSIONS}

In this contribution a short analysis of the Lisbon articles and some ECJ cases has been given. The cases deal with the interpretation of Framework Decisions of the old Third Pillar and their impact on the area of freedom, security and justice on the national legal order. In these ECJ judgments delivered before the entry into force of the Lisbon Treaty the protection of human rights and its principles were already included. However, one of the most important new constitutional developments of the Lisbon Treaty for our topic is the entry into force of Article 6 (1) TEU, which holds that the Charter of Fundamental Rights shall have the same legal value as the Treaties. As a consequence many ECJ Decisions are more or less outdated since Lisbon as the need that was put forward in the ECJ Decisions for more protection of human rights in the areas of police and judicial cooperation and direct effect of Framework Decisions are now unnecessary since reference to the articles of the Charter will now be preferred.

The introduction of more human rights protection by the European Court of Justice is expected, taking into consideration the planned accession of the EU to the European Convention on Human Rights and the binding legal status of the Charter adopted with the Lisbon Treaty. In the referred and discussed pre-Lisbon ECJ cases and Opinion of Advocate General the need for protection of human rights and for the Charter of Fundamental Rights has been explicitly mentioned. Guaranteeing equal human and fundamental rights protection at EU level will enhance mutual trust among Member States.

Another important constitutional development on the impact of AFSJ on the national legal order is the new Lisbon provisions from Article 288-294 TFEU on the regulations, directives and decisions. They will have more direct effect and applicability than the respective measures as common positions, framework decisions, decisions and conventions from Article 34 of the EU Treaty of Nice. Article 34 has held that framework decisions and other decisions would have no direct effect. As in the Lisbon Treaty direct effect is not excluded, this is an important constitutional change.

The Acts of Article 288 TFEU can be therefore more effective, since they can have supremacy and direct effect.
Moreover can the new infringement procedure of Articles 259 and 260 TFEU contribute to a better and more timely implementation of EU law obligations in the Area of Freedom, Security and Justice?

The third constitutional development concerns the fact that the Lisbon Treaty has brought all provisions concerning AFSJ within the "normal" "Community" Treaty structure. As a consequence the jurisdiction of the ECJ extends to all EU acts. The Lisbon Treaty made a major change in regard to the limits of the preliminary rulings procedure and legality review in the area of the AFSJ. They will mostly be equally treated as the other subject matters falling within Article 267 TFEU, with exceptions in the area of police and judicial cooperation in criminal matters.

A fourth constitutional development is that the national Parliaments have within decision-making of AFSJ a more important role than before Lisbon, compared also with their role in the decision-making in the internal market.

The introduction of supremacy in the First Pillar was necessary for ensuring uniformity of application of EC law as a condition for the establishment of the internal market with free movement of goods, services and capital. It is admitted that the same rationale does not apply in the Third Pillar for the free movement of persons (see S Prechal, "Direct Effect, Indirect Effect, Supremacy and the Evolving Constitution of the European Union", in C Barnard, The Fundamentals of EU Law Revisited (Oxford University Press 2007), 35, 41).

Does this mean as the citation of $\mathrm{K}$ Lenaerts suggests that all national law conflicting with Third Pillar EU law has to be simply set aside? Does it mean that Third Pillar EU law is capable of overriding national constitutions? A partial judicial answer to these questions were given in the case C-303/05, Advocaten voor de Wereld. National standards of review may be replaced by European standards. The centrality of mutual recognition is now laid down in the Lisbon Treaty. However the lack of mutual trust and lack of procedural safeguards at EU level are weak aspects that impact negatively on the further enhancement of police and judicial cooperation within the EU. Also the sensitivity of the area is an obstacle to transferring more national powers to the European Union.

\section{Alfred Kellermann}

Senior EU Legal and Policy Advisor; Visiting Professor in European Law. 